\title{
Attitudes of Students towards Entrepreneurship Education at Two Selected Higher Education Institutions in Botswana: A Critical Analysis and Reflection
}

\author{
1Dr. Norman Rudhumbu
}

Assistant Fellow, Botho University, Gaborone, Botswana, Corresponding author

2Douglas Svotwa

Senior Lecturer, Botho University, Gaborone, Botswana

${ }^{3}$ Dr. Takaruza Munyanyiwa

Pro Vice Chancellor Business Development, University of Zimbabwe (UZ), Mount Pleasant, Harare, Zimbabwe

${ }^{4}$ Morgen Mutsau

Center for Applied Social Sciences (CASS), University of Zimbabwe (UZ), Mount Pleasant, Harare, Zimbabwe

Doi:10.5901/ajis.2016.v5n2p83

\section{Abstract}

The study examined the attitudes of undergraduate fourth year students towards entrepreneurship education. Studies show that entrepreneurship has become a critical area of discussions the world over due its perceived role in mitigating the twin challenges of shrinking economies and unemployment. A sample of 250 students from a population of 462 students was used in the study. A structured questionnaire that employed a 5-point Likert scale was used for data collection. Results of the study showed that most students have a positive attitude towards entrepreneurship education and would prefer to be entrepreneurs at the end of their studies. Results of the study further showed that challenges that may affect students' interest in entrepreneurship education and entrepreneurship as a career include difficulty in accessing funding, lack of technical support at start-up, and inadequate business opportunities in Botswana.

\section{Introduction}

Studies show that our world has become global, uncertain and complex and hence requires people with creative, complex and diversified entrepreneurial knowledge and skills to answer to the twin challenges of shrinking economies and unemployment (Iqbal, Melhem\&Kokash, 2012). Markets are currently only offering limited job opportunities for university graduates (Frazao, Santos, Oliveira \& Oliveira, 2010).

The above is confirmed by Teshome (2014) who argued that the world over, university and college graduates are now finding it difficult to secure employment in both public and private enterprises due to the current volatile economic environment hence the need to focus on entrepreneurship as a gateway to employment creation and stabilizing economies.

Due to the now perceived critical importance of entrepreneurship, a number of studies the world over and specifically in Botswana have been conducted with a view to establishing how much of a vehicle to socio-economic development the idea of entrepreneurship is. As for Botswana whichhas an unemployment rate of $18 \%$ which continues to grow (Statistics Botswana, 2011), the issue of entrepreneurship is considered very important for economic growth and for solving the scourge of unemployment. It is important to note that Botswana experienced a strong and fast growing economy since independence in 1966 but unfortunately over the past couple of decades it began to experience the twin challenges of unemployment and the need to diversify the economy as global macro-economic fundamentals began to take a nose dive (Botswana Review, 2007-2008). The main stay of the Botswana economy are diamonds and the falling prices of these diamonds resulted in the shrinking of the economy and failure by industry to create jobs for the large numbers of graduates leaving the higher education system (Statistics Botswana, 2011). The importance of entrepreneurship in Botswana therefore became and continues to be a talking point in government circles as is vividly 
articulated in the National Development Plan 9 of 2003 in the Botswana Vision 2016. The Vision 2016 is a thirty-year programme of action which was promulgated in 1996 to promote entrepreneurship as one of its mandates (Botswana Vision 2016; Cloete, Bailey, Pillay, Bunting \&Maassen, 2011).

While it is accepted that entrepreneurship in Botswana is still work in progress (Mapfira\& Setibi, 2014), the government of Botswana and its partners, in their attempts to ensure the success of entrepreneurship, introduced a number of initiatives. On the part of government the major initiatives it introduced to support the development of entrepreneurship culture in the country included the creation of two main parastatals namely the Citizen Entrepreneurial Development Agency (CEDA) and the Local Enterprise Authority (LEA) to spear head the entrepreneurship crusade (Mapfaira \& Setibi, 2014). These two bodies provided funding and technical expertise to prospective entrepreneurs (Republic of Botswana, 2003).

As of now there are ten institutions and organisations from government and private players that support entrepreneurship in Botswana through funding, training and other technical expertise namely CEDA, LEA, Youth Development Fund, Young farmers' Fund, Kgalagadi Brewery Limited-KICKSTART, NCONGO-Youth in Botswana, Embasy of the USA, Debswana-PEO, Banks, and Botswana Innovation Hub (Botswana youth Magazine, 2015).

As part of contributions to support government efforts to stimulate entrepreneurship in order to alleviate the twin challenges of unemployment and the need to diversify the economy, public and private higher education institutions have also introduced entrepreneurship programmes (Mafela, 2009).

As a result of the perceived importance of entrepreneurship across the divide in Botswana, a number of researchers have undertaken studies in the area. Unfortunately all the studies conducted in Botswana with regards to the perceptionsor attitudes of students towards entrepreneurship and entrepreneurship education were conducted in public higher education institutions and none in private higher education institutions. This study is therefore meant to fill that research gap.

\section{Objectives of the Study}

- To investigatethe attitude of students towards entrepreneurship education.

- To examine how demographic characteristics of students influence students attitude towards entrepreneurship education.

- To investigate whether students view entrepreneurship as a future career.

- To identify factors that influence entrepreneurship intentions of students.

\section{Hypotheses}

- There is a significant relationship between gender of students and attitude towards entrepreneurship education.

- There is a significant relationship between area of specialisation of studentsand attitude towards entrepreneurship education.

- There is a significant relationship between age of students and attitude towards entrepreneurship education.

- There is a significant relationship between students' participation in entrepreneurship education and their view of entrepreneurship as a future career.

\section{Literature Review}

The importance of entrepreneurship in alleviating economic and social challenges facing society is now a theme of heightened discussion the world over (Lekoko, 2011). The above is echoed by Ramalan and Ngah (2012) who averred that entrepreneurship is a critical agent for economic growth.Literature further attests to the fact that in many countries especially emerging economies, graduate unemployment has become an albatross around the neck of society in general and school leavers in particular (Opoku-Antwi, Amofah, Nyamaah-Koffuor\&Yakubu (2012), hence the current clamour for entrepreneurship and entrepreneurship education in higher education institutions. The issue of entrepreneurship as a vehicle to self-employment is further emphasised by Lokoko, Rankhumise and Ras (2012) who argued that the move towards self-employment the world over is and will continue to become an increasingly important element of economic growth and development. 
Entrepreneurship is further viewed as an important driver for economic growth, productivity and social development and hence is perhaps one of the main issues in current public policy debate (Denanyoh, 2015). Demonstrating the importance of entrepreneurship in boosting economic growth, the Global Entrepreneurship Monitor (GEM) (2006) indicated that as much as one-third of the differences in economic growth among nations may be attributed to differences in entrepreneurship activity.

Fostering an entrepreneurial culture among the university graduates has therefore become an issue of great priority (Gerba, 2012) such that developing an opportunity-oriented mindset in university students is now considered very critical. The above is so because entrepreneurship is now viewed as a cog in the socio-economic performance of countries due to its potential and capacity to create employment opportunities (Mustapha \&Selvaraju, 2015).

In the context of Botswana, as mentioned above, studies show that the rate of unemployment was at $18 \%$ as of 2011 and has been rising ever since, with the majority of the unemployed being youths (Statistics Botswana, 2011). This result according to Lekoko (2011) paused a challenge for higher education institutions in Botswana to come up with programmes such as entrepreneurship education to help youths gain knowledge and skills to create their own jobs and be self-employed. The above point by Lekoko dovetails with views of Emanuel, Dazala and Daniel (2012) who argued that for far too long, higher education institutions have been concentrating on producing graduates for whom there is no market rather than concentrate on programmes such as entrepreneurship that help in job creation. Eugene, Adline and Agwubuike (2013) also opined that higher education institutions needed to be criticized for producing job-seeking rather than job-creating, self-reliant graduates.

\subsection{The concept of entrepreneurship}

Entrepreneurship is viewed as a multi-dimensional construct that is defined variously by different people hence there is no unified definition. According to Mokaya, Namusongeand Sikalieh (2012), entrepreneurship is the individual motivation and willingness to take risk, create and sustain a growth-oriented and profit-making enterprise. Entrepreneurship is also viewed as a cultural and economic phenomenon (Gzozdanic, et al., 2008), a process of fundamental transformation from an innovative idea to an enterprise, from an enterprise to creation of value (The Kauffman Panel Report, 2007). According to Teshome (2014) and also Odunaike and Amoda (2013), entrepreneurship is the art of setting up and running an enterprise in a profitable and sustainable manner. The above definitions therefore imply that an entrepreneur is somebody who is innovative, daring and who is able to identify opportunities where others see risks. As also given by Mazura and Norasmah (2011) the above definitions also mean that entrepreneurship is a long term strategy for reducing unemployment and boosting economic development through the exploitation of business opportunities available.

\subsection{The concept of entrepreneurship education}

The history of entrepreneurship education dates back to the 1930s in Japan through the works of a Japanese professor though most of modern day entrepreneurship sources and programmes were pioneered and introduced in schools by American universities (Keat et al, 2011). The aim of theseprogrammeswas to produce graduates who were able not only to identify opportunities but to turn those opportunities into businessesBilic, Prka\&Vidovic, 2011). Entrepreneurship education is viewed as a means of developing entrepreneurial skills in people, which skills manifest through creative strategies, innovative tactics, uncanny identification of trends and opportunities in the market, and courageous leadership (Gerba, 2012). Fayolle and Klandt (2006) on the other hand view entrepreneurship education as a three-dimensional construct, that is, as a matter of culture or state of mind, as a matter of behaviour, and as a matter of creating specific situations.

Entrepreneurship education as a matter of culture or state of mind encompasses those aspects of entrepreneurship education that focus on values, beliefs and attitudes as these play a critical role in shaping one's attitude towards entrepreneurship, entrepreneurship intentions or inclination. Entrepreneurship education as a matter of behaviour relates to specific skills such as identifying and seizing opportunities, making informed decisions and developing social skills to be able to communicate well with stakeholders. Entrepreneurship education as a matter of creating specific situations relates to influence of entrepreneurship in the creation of new ideas, new firms and enterprises (Fayolle\&Klandt, 2006).

The above multi-dimensional conception of entrepreneurship education is also highlighted by Mapfaira and Setibi (2014) who argued that meaningful entrepreneurship education is an attempt at fostering entrepreneurial awareness as a career option through the enhancement of the understanding in students of the process of initiating and managing a 
business. This process should therefore cover the following: i) education about entrepreneurship (entrepreneurship awareness), ii) education for enterprise (preparation of aspiring entrepreneurs for business creation, iii) education in enterprise (training for the growth and development of established enterprises), and iv) provision of business skills that are needed to successfully start and manage a new business (Mapfaira \& Setibi, 2014). Shaver and Scott (1992) in McStay (2008) also echo the same sentiments about entrepreneurship education when they averred that entrepreneurship education should move and has moved from the study of business plans and personality traits to the exploration of entrepreneurial behaviour, motivation and cognition to get people off their feet and confidently start a business.

The above conceptualisation of entrepreneurship education implies that such education should not just be about writing business plans (learning about entrepreneurship) but should be about developing an entrepreneurship mindset and also developing an enterprise behaviour (learning for entrepreneurship) (Honig, 2004). If people are to be interested in entrepreneurship and entrepreneurship education, the main focus of entrepreneurship education should therefore be the development of skills of how to start and run a business not knowledge how to plan for it. Entrepreneurship education should be a form of empowerment that not only develop but also support entrepreneurial activities, behaviours and mindsets (Ekpoh\&Edet, 2011). In the end and according to the Global Entrepreneurship Monitor (GEM) (2010), entrepreneurship education should eventually be viewed as an intervention to create jobs, to drive and shape innovativeness and to stimulate economic growth.

\subsection{Components of entrepreneurship attitudes}

Entrepreneurship education is viewed as a form of training in entrepreneurial knowledge, behaviour, attitudes and skills (Pulka et al, 2014). As a result, students' attitudes towards entrepreneurship and entrepreneurship education can be measured in terms of three components of entrepreneurship attitudes namely cognitive, affective and behavioural attitude components (Pulka et al, 2014). The cognitive component relates to beliefs, thoughts and knowledge students have about entrepreneurship and entrepreneurship education that shape their attitudes and behaviours (Amdam, 2011). The affective component relates to feelings and emotions about entrepreneurship and entrepreneurship education, that is, how a person sees the desirability or relevance of something and hence whether eventually they either like it or not (Kulpa et al, 2014). The behavioural component relates to actions, overt responses and willingness to respond to or accept something (Mani, 2008).

\subsection{Previous studies on entrepreneurship and entrepreneurship education}

A study by Souitaris, Zerbinati and Andreas (2007) found that entrepreneurship education stimulates students' subjective norms and intentions towards entrepreneurship by providing them with knowledge, skills and a sense of belief that inspire them to choose entrepreneurship as a career. In another study by Basu and Virik (2008), it was found that entrepreneurship education improves attitudes of students towards entrepreneurship. These results were also confirmed in another study by Ediagbonya (2013) whose results showed that by developing skills, knowledge and motivation in university students for them to successfully engage in entrepreneurship activities, entrepreneurship education positively impacts on the attitudes of students towards entrepreneurship.

In a study by the Kauffman Foundation (2000), it was found that entrepreneurship education increased the probability of start-ups, self-employment and also that it enhances the likelihood of economic reward and self-satisfaction of the entrepreneur. A study by lqbal et al (2012) also showed that after they had participated in entrepreneurship education, most students believed that: i) if they start their own business, they would have a high probability of success, ii) they were better prepared to start their own businesses, and iii) the entrepreneurship education programme had given them enough knowledge and skills to successfully start their own businesses.

In yet another study by Zain, Akram and Ghani (2010) it was found that more than 50\% of students had an intention to become entrepreneurs after going through the entrepreneurship programme while Mapfaira and Setibi (2014) indicated in their study that the number was as high as 73\%. This is also confirmed by a study by Kabui and Maalu (2012) which found that most students who had gone through the entrepreneurship course had a positive perception of entrepreneurship as a future career though the same results also showed that factors that included fear of failure, and lack of sufficient capital were some of the major barriers to the students' intentions to start their own businesses.

In different studies on the influence of biographic characteristics, personal attributesof students, successful entrepreneurs, and supportive environment on the entrepreneurship intentions of students, a number of results were 
found. A study by Ismael, Abdullah and Othman (2010) on the influence of gender on the inclination of students towards entrepreneurship found that there was a significant difference in their attitudes towards entrepreneurship between male and female students. However, another study by Pour, Nooriaee and Heydari (2013) found that age, gender and area of specialisation have no significant influence on the entrepreneurship inclination of a student.

In a study by Kirby (2004) on whether personal attributes of students had an effect on their attitudes towards entrepreneurship, results showed that more independent and outgoing students had a higher inclination than their counterparts. Use of successful entrepreneurs as guest speakers was also found by Bergh, Thorgren\&Wincent (2011) to have a positive effect on students' attitudes towards entrepreneurship. A supportive university environment was also found to have a positive impact on the entrepreneurship inclination of students (Sriram, Mersha and Herron, 2007).

Studies on entrepreneurship and entrepreneurship education also identify challenges which students say have potential to affect their entrepreneurship intentions.A study by Mapfaira and Setibi (2014) found that students identified lack of technical support, difficulty in accessing finance as well as general poor attitude of people towards entrepreneurship were some of the hindrances to the entrepreneurship intentions.

\section{Methodology}

\subsection{Research design}

This study employed a descriptive research design that uses a survey strategy for data collection. A descriptive research is all about describing people who take part in the study so as to provide information about the naturally occurring status, behavior, attitudes or other characteristics of a particular group (Kowalczyk, 2015). The major reason why a descriptive survey was selected for this study was to enable the researchers to capture views from a large cross section of the population of respondents thus ensuring that a variety of ideas whether conflicting or agreeing on the attitudes of students towards entrepreneurship education, are included in the study.

\subsection{Population and sampling}

The population of the study consisted of 462 undergraduate students who went through the entrepreneurship programme at the two selected private universities in Botswana. These students were fourth year undergraduate students as entrepreneurship in these institutions is only done by students at that level. Private higher education institutions in Botswana are defined as only those institutions offering academic qualifications up to degree level (Tertiary Education Council (TEC), 2005).

Convenience sampling was used to select the two universities based on the fact that they had been offering the programme for a longer period when compared to other institutions. Stratified random sampling was also used to select a sample of 250 students. Stratified random sampling refers to a method of sampling that involves the division of a population into smaller groups known as strata (Creswell, 2005). In stratified random sampling, the strata are formed based on members' shared attributes or characteristics (Creswell \& Plano Clark, 2011). A random sample from each stratum (institution)was taken in a manner proportional to the stratum's size when compared to the population andthese subsets of the strata (institutions)were then pooled to form a random sample.

\subsection{Instrumentation}

A structured questionnaire was used for data collection. A structured questionnaire is defined as a research instrument based predominantly on closed questions which produce data that can be analyzed quantitatively for patterns and trends (Creswell, 2012). The questionnaire employed a 5-point Likert scale from strongly agree (SA), Agree (A), Neutral (N), Disagree (DA) to strongly disagree (SDA) with each of the points assigned a value as follows: $S A=5, A=4, N=3, D A=2$, SDA $=1$.

Before being administered, the questionnaire was subjected to reliability and validity testing. Using the Cronbach Alpha test, the questionnaire was tested for internal consistency reliability. The awas calculated and was found to be equal to .074 hence the questionnaire was considered reliable enough for the study. With regards to validity, the questionnaire was subjected to expert opinion for content validity and recommendations from the experts were factored into the final questionnaire. Of the 250 questionnaires administered, 196 were returned giving a return rate of $78.4 \%$. 


\section{Results}

\subsection{Analysis of descriptive data}

Descriptive and inferential statistics will be used to present and analyse results. Responses of Strongly Agree (SA), Agree (A), Neutral (N), Disagree (DA) and Strongly Disagree (SDA) were weighted as 5, 4, 3, 2, and 1 respectively. The sum of the weights was divided by 5 to get a criterion mean of 3 so that responses with mean scores of less than 3 were not accepted and meant negative attitudes towards entrepreneurshipeducation and those with mean scores of 3 to 5 were accepted as representing marginal to positive to very positive attitudes of students towards entrepreneurship education. SPSS version 21 was used to assist in the analysis of the quantitative data.

Table 1: Demographic variables $(N=196)$

\begin{tabular}{|l|c|}
\hline Demographic variable & Number of students \\
\hline Age: & $65.2 \%$ \\
\hline $16-20$ & $18.8 \%$ \\
\hline $21-24$ & $16 \%$ \\
\hline $25^{+}$ & $47.6 \%$ \\
\hline Gender: & $52.4 \%$ \\
\hline Male \\
\hline Female & $44.8 \%$ \\
\hline Area of specialisation: & $26.8 \%$ \\
\hline Software engineering & $28.4 \%$ \\
\hline Networking engineering & \\
\hline Teeside programme &
\end{tabular}

Results in Table 1 show that there were more femalestudents (52.4\%)that there were male students (47.6\%) in the entrepreneurship programme. Table 1 further shows that most of the students in the programme were aged between 16 and 20 years while the least number of students were aged above 25 years. Finally, most of the students in the programme were from the software engineering programme (44.8\%) while the least number (26.8\%) was from the networking engineering programme.

Table 2: Behavioural Component of students' attitudes $(\mathrm{N}=196)$

\begin{tabular}{|c|c|c|}
\hline Item & Mean & Std. Dev. \\
\hline I enjoyed entrepreneurship education lessons & 4.06 & 1.3 \\
\hline Entrepreneurship education lessons increased my interest in a career in entrepreneurship & 4.15 & 0.9 \\
\hline I consider entrepreneurship as being as important if not more important than any other subject & 4.37 & 1.3 \\
\hline Entrepreneurship education prepared me to make innovative and informed decisions about career choices & 3.48 & 1.1 \\
\hline I am happy to have learned entrepreneurship education & 3.27 & 1.4 \\
\hline I consider entrepreneurship a desirable career option & 4.24 & 1.1 \\
\hline The university encouraged students to pursue entrepreneurship ventures & 3.17 & 1.0 \\
\hline The university and my lecturers helped me to meet and interact with people with good entrepreneurial ideas & 3.01 & 1.1 \\
\hline My institution helped me to meet successful entrepreneurs who motivated me towards entrepreneurship as a career & 3.09 & 1.1 \\
\hline The university and my lecturers helped me to meet and interact with people with good entrepreneurial ideas & 2.03 & 1.2 \\
\hline Average & 3.49 & 1.2 \\
\hline
\end{tabular}

$\mathrm{M}=$ Mean Score

Results in Table 2 show that there is a willingness and acceptance by most of the students $(3<M \leq 5)$ that entrepreneurship is a desirable career option and that entrepreneurship education is important in preparing them to become entrepreneurs. The mean of mean scores of 3.49 also indicates that for most students their behavioural attitude towards entrepreneurship and entrepreneurship education is positive. Of the 10 items measuring behavioural attitude towards entrepreneurship, 4 items with mean scores of 4 and above $(4 \leq M \leq 5)$ demonstrate that 
Table 3: Cognitive component of students' attitudes

Students have a very positive behavioural attitude towards entrepreneurship as a result of taking part in entrepreneurship education. Of the 10 items measuring behavioural attitude of students, 5 items with mean of score $3 \leq M<4$ show that students have a fairly high behavioural attitude towards entrepreneurship and entrepreneurship education. Only in one item out of 10 do students show a negative behavioural intention towards entrepreneurship and entrepreneurship education.

\begin{tabular}{|c|c|c|}
\hline Item & Mean & Std. Dev. \\
\hline Due to entrepreneurship education, I am able to identify business opportunities & 3.03 & 1.2 \\
\hline Due to entrepreneurship education, I can now create products and services that satisfy customers & 3.01 & 1.0 \\
\hline Due to entrepreneurship education I can successfully develop business plans & 3.74 & 1.1 \\
\hline Due to entrepreneurship education, I now have skills to can create a new business & 4.84 & 1.2 \\
\hline Due to entrepreneurship education, I can now successfully identify sources of business finance & 3.85 & 1.0 \\
\hline $\begin{array}{l}\text { Due to entrepreneurship education, I can now anticipate, tolerate and manage unexpected market changes, } \\
\text { setbacks and risks that may affect my business }\end{array}$ & 3.54 & 1.1 \\
\hline Due to entrepreneurship education, I can perform feasibility studies to check if my business ideas work & 2.73 & 1.3 \\
\hline Modules in the entrepreneurship programme stimulated my interest in entrepreneurship & 4.62 & 1.1 \\
\hline $\begin{array}{l}\text { Practical examples as well as use of guest speakers such as successful entrepreneurs helped me understand } \\
\text { entrepreneurship better }\end{array}$ & 4.38 & 1.2 \\
\hline Through entrepreneurship education, my knowledge, skills and interest in entrepreneurship have overall improved & 4.33 & 1.2 \\
\hline Overall I was very happy and satisfied with how the entrepreneurship programme was taught & 3.51 & 1.0 \\
\hline Average & 3.47 & 1.0 \\
\hline
\end{tabular}

Table 3 shows that most of the students believe that the entrepreneurship education they participated in developed knowledge and skills for them to effectively participate in entrepreneurship activities. This is shown by the mean scores $3 \leq M \leq 5$ where in 10 out of 11 items measuring the cognitive component of students attitudes towards entrepreneurship and entrepreneurship education, students showed positive cognitive intentions. Out of the 10 items where students showed high cognitive intentions towards entrepreneurship as a result of participating in entrepreneurship education, in 4 items students showed very high positive intentions $(4 \leq M \leq 5)$ and in 6 out of the 10 items, students showed fairly high entrepreneurship intentions $(3 \leq \mathrm{M}<4)$.It is only in 1 out of the 11 items that students showed very low entrepreneurship intentions $(M<3)$. A mean of mean scores of $M=3.47$ shows that overall students had a positive cognitive intention towards entrepreneurship and entrepreneurship education.

Table 4: Affective component of students' attitudes ( $N=196)$

\begin{tabular}{|l|c|c|}
\hline Item & Mean & Std. Dev. \\
\hline I want to work for myself after completing school & 3.94 & 1.0 \\
\hline The idea of working for myself is very appealing to me & 4.12 & 1.4 \\
\hline I consider self-employment as very important & 3.98 & .93 \\
\hline My personal satisfaction with self-employment is very high & 3.79 & 1.3 \\
\hline The university entrepreneurship programme effectively prepared me for an entrepreneurial career & 3.15 & .90 \\
\hline I want to work for myself after completing school & 3.64 & 1.2 \\
\hline Average & 3.83 & 1.1 \\
\hline
\end{tabular}

Table 4 shows that the general feeling and emotional disposition of students towards entrepreneurship and entrepreneurship education is positive as in all the 6 items measuring the affective component of students' attitudes towards entrepreneurship the mean score is above 3 , that is $(3 \leq M \leq 5)$. In one item where $M \geq 4$, students showed a very high positive attitude towards entrepreneurship and entrepreneurship education while in the remaining 5 items where $3<M \leq 4$, the attitude was generally satisfactory. The mean of mean scores of $M=3.83$ shows that overall the affective intentions of students towards entrepreneurship and entrepreneurship education is positive.

Table 5: Challenges that may affect student interest in entrepreneurship ( $N=196)$

\begin{tabular}{|l|c|c|}
\hline Item & Mean & Std. Dev. \\
\hline Inadequate business opportunities & 3.92 & .91 \\
\hline
\end{tabular}




\begin{tabular}{|l|c|c|}
\hline Lack of entrepreneurship knowledge and skills & 1.45 & 1.5 \\
\hline Difficult in accessing funding & 4.14 & 0.87 \\
\hline Lack of start-up technical support such as how to write a winning business plan & 3.95 & 1.1 \\
\hline Legislation which is not business-friendly & 1.98 & 1.0 \\
\hline Average & 3.09 & 1.1 \\
\hline
\end{tabular}

Table 5 shows the challenges that act as barriers to students' entrepreneurship intentions. The main challenge that has an effect on the interest and hence attitude of students towards entrepreneurship education and entrepreneurship even after going through the entrepreneurship course is difficulty in accessing funds $(M \geq 4)$. Challenges with a moderate effect on students' interest hence negatively affect their attitude towards entrepreneurship are lack of technical support ( $M=$ 3.95) and lack of business opportunities $(M=3.92)$. Students believe legislation $(M=1.98)$ is supportive of efforts to start new business also that they do not lack of entrepreneurship knowledge and skills $(M=1.45)$.

Table 6: Overall measurement of attitudes of students towards entrepreneurship education

\begin{tabular}{|l|c|c|}
\hline Students attitude component & Mean & Std. Dev. \\
\hline Cognitive component & 3.47 & 1.0 \\
\hline Affective component & 3.83 & 1.1 \\
\hline Behavioural component & 3.49 & 1.2 \\
\hline Mean of mean scores & 3.60 & 1.1 \\
\hline
\end{tabular}

Table 6 shows that overall, the attitude of students towards entrepreneurship and entrepreneurship education is positive $(M=3.60)$. This shows that entrepreneurship education has been effective in motivating students to view entrepreneurship as a future career option

\subsection{Hypothesis testing}

The non-parametric Chi-square was used to test hypotheses. Hypotheses were tested at $1 \%$ level of significance which is more sensitive to outlays than the $5 \%$ level of significance. education.

Hypothesis 1: There is a significant relationship between gender of students and attitude towards entrepreneurship

Table 7: Gender and entrepreneurship attitude ( $N=196)$

\begin{tabular}{|l|c|c|c|c|c|c|c|}
\hline & $\begin{array}{c}\text { Strongly } \\
\text { Agree }\end{array}$ & Agree & Neutral & Disagree & $\begin{array}{c}\text { Strongly } \\
\text { Disagree }\end{array}$ & $\begin{array}{c}\text { Chi- } \\
\text { Square }\end{array}$ & $\begin{array}{c}\text { Asymp. } \\
\text { Sig. }\end{array}$ \\
\hline $\begin{array}{l}\text { There is a significant relationship between gender of } \\
\text { students and attitude towards entrepreneurship education }\end{array}$ & 63 & 30 & 14 & 81 & 8 & $48.058^{a}$ & .041 \\
\hline
\end{tabular}

The calculated P-Value on Table 7 shows that $P>0.01$ which is not statistically significant, hence the hypothesis that there is a relationship between gender and students' attitudes towards entrepreneurship education was accepted. The frequency of positiveresponses was greater than that of negative responses showing that many students agreed that there is a relationship between gender and how students view entrepreneurship education as important.

Hypothesis 2: There is a significant relationship between area of specialisation of studentsand attitude towards entrepreneurship education.

Table 8: Area of specialisation and entrepreneurship attitude

\begin{tabular}{|l|c|c|c|c|c|c|c|}
\hline & $\begin{array}{c}\text { Strongly } \\
\text { Agree }\end{array}$ & Agree & Neutral & Disagree & $\begin{array}{c}\text { Strongly } \\
\text { Disagree }\end{array}$ & $\begin{array}{c}\text { Chi- } \\
\text { Square }\end{array}$ & $\begin{array}{c}\text { Asymp. } \\
\text { Sig. }\end{array}$ \\
\hline $\begin{array}{l}\text { There is a significant relationship between area of pecialisation } \\
\text { of students and attitude towards entrepreneurship education. }\end{array}$ & 71 & 13 & 6 & 66 & 40 & $34.25^{\mathrm{a}}$ & .000 \\
\hline
\end{tabular}

The calculated P-Value in Table 8 shows that $P<0.01$ which is statistically significant, hence the hypothesis was rejected, indicating that there is no significant relationship between area of specialisation of students and attitudes 
towards entrepreneurship education. This result confirms earlier results on Table 6 that showed that across areas of specialisation, in all the three components that measure attitudes, students attitudes towards entrepreneurship education is very positive.

Hypothesis 3: There is a significant relationship between age of students and attitude towards entrepreneurship education.

Table 8: Age and entrepreneurship attitudes

\begin{tabular}{|l|c|c|c|c|c|c|c|}
\hline & $\begin{array}{c}\text { Strongly } \\
\text { Agree }\end{array}$ & Agree & Neutral & Disagree & $\begin{array}{c}\text { Strongly } \\
\text { Disagree }\end{array}$ & $\begin{array}{c}\text { Chi- } \\
\text { Square }\end{array}$ & $\begin{array}{c}\text { Asymp. } \\
\text { Sig. }\end{array}$ \\
\hline $\begin{array}{l}\text { There is a significant relationship between age of students } \\
\text { and attitude towards entrepreneurship education. }\end{array}$ & 123 & 5 & 18 & 34 & 16 & $39.48^{\mathrm{b}}$ & .027 \\
\hline
\end{tabular}

As shown on Table 8, the P-Value was statistically significant as $(P>0.01)$ level of significance which is not statistically significant hence the hypothesis that there is a significant relationship between age and students' attitudes towards entrepreneurship education was accepted. The null hypothesis that there is no significant relationship between age of students and attitude towards entrepreneurshipeducation was rejected.

Hypothesis 4:There is a significant relationship between students' participation in entrepreneurship education and their attitude towards entrepreneurship as a future career.

Table 9: Entrepreneurship education and entrepreneurship attitude ( $N=196)$

\begin{tabular}{|l|c|c|c|c|c|c|c|}
\hline & $\begin{array}{c}\text { Strongly } \\
\text { Agree }\end{array}$ & Agree & Neutral & Disagree & $\begin{array}{c}\text { Strongly } \\
\text { disagree }\end{array}$ & $\begin{array}{c}\text { Chi- } \\
\text { Square }\end{array}$ & $\begin{array}{c}\text { Asymp. } \\
\text { Sig. }\end{array}$ \\
\hline $\begin{array}{l}\text { There is a significant relationship between students' } \\
\text { participation in entrepreneurship education and their attitude } \\
\text { towards entrepreneurship as a future career. }\end{array}$ & 96 & 23 & 8 & 47 & 22 & $13.47 \mathrm{a}$ & .086 \\
\hline
\end{tabular}

The calculated $P$-value on Table 9indicates that $(P>0.01)$, showing that this was not statistically significant hence the hypothesis that the there is a significant relationship between students' participation in entrepreneurship education and their attitude towards entrepreneurship intention is accepted. This result also confirmed earlier results in Table 3 that showed that most students $(M=4.62)$ believe that entrepreneurship education helped to motivate them to become entrepreneurs.

\section{Discussion}

Results of the study show that the overall attitude of students towards entrepreneurship education has a mean score of 3.60 which shows a positive attitude. It is also shown in the results that students believe that their participation in entrepreneurship education helped to stimulate their interest in entrepreneurship, and this is a further demonstration of how positive the attitudes of students are towards entrepreneurship education. This result confirms earlier studies by Sonitariset al (2007) and also by Basu and Virik (2008) which found that entrepreneurship education stimulates students' subjective norms and intentions towards entrepreneurship. Ediagbonya (2013) in his study also found that by developing skills, knowledge and motivation in university students for them to be able to successfully engage in entrepreneurship activities, entrepreneurship education positively impacts on the attitudes of students towards it and towards entrepreneurship. Iqbal et al (2012) in their study also found that after students had participated in entrepreneurship education, most students believed that: i) if they start their own business, they would have a high probability of success, ii) they were better prepared to start their own businesses, and iii) the entrepreneurship education programme had given them enough knowledge and skills to successfully start their own businesses. This is again a sign that students have a positive attitude towards entrepreneurship education as they see it as benefiting them in the end.

The positive attitude of students towards entrepreneurship education is therefore an indication that most of them understand and view entrepreneurship education as an attempt foster entrepreneurial awareness as a career option through the enhancement of the understanding in students of the process of initiating and managing a business (Mapfaira 
and Setibi, 2014).The above is also confirmed by Gerba (2012) who argued that having a positive attitude towards entrepreneurship education implies having an appreciation of entrepreneurship education as an important means of developing entrepreneurial skills in people which skills manifest through creative strategies, innovative tactics, uncanny identification of trends and opportunities in the market. Having a positive attitude towards entrepreneurship also means that students, just like all other people in this volatile economic environment, have come to an understanding and appreciate that the twin challenges of unemployment and the shrinking of economies, as articulated by Iqbal et al (2012), can be solved or at least minimised by empowering people with entrepreneurial skills through entrepreneurship education. The above assertions are also confirmed by a study by Zain et al (2010) who found that more than $50 \%$ of students intended to become entrepreneurs after going through the entrepreneurship programme while a study by Mapfaira and Setibi (2014) found that $73 \%$ of students were willing to start their own businesses after going through entrepreneurship education.

The study also looked at the influence of demographic characteristics of students that include gender, age and area of specialisation on their attitude towards entrepreneurship. Results showed that gender has an influence on how students perceive entrepreneurship education as male students indicated more willingness to and satisfaction in participating in entrepreneurship education than female students. The above results confirm earlier results in a study by Ismael et al (2010) which found that there were significant differences in attitudes between male and female students with male students believing that entrepreneurship is important in shaping their future careers. With regards to the influence of age of students on their attitude towards entrepreneurship education, results of the study showed that age had a significant influence on the attitude of students towards entrepreneurship education. The study showed that older students (21-24 years and $25^{+}$years) had a more positive attitude towards entrepreneurship than students in the 16-20 years bracket who had a positive attitude but not as high as that of the upper age groups. A study by Pour et al (2013) however found that age did not have an influence on the attitude of students towards entrepreneurship education and entrepreneurship as a future career. The current study also showed that area of specialisation did not have an influence on how students perceive entrepreneurship education which confirmed an earlier study by Pour et al (2013) that also showed that area of specialisation did not have a significant influence on the entrepreneurship inclination of students.

Results of the study also showed that there are a number of challenges that affect students' entrepreneurship intentions. It was revealed in the study that difficult in accessing funding, lack of start-up support as well as inadequate business opportunities were some of the challenges that may affect their entrepreneurship intentions despite having successfully gone through the entrepreneurship programme. Results further showed that students felt that the entrepreneurship course had given enough knowledge and skills to start their own business and the issue of knowledge and skills was not a challenge. Results also show that legal environment in Botswana is pro-business hence laws of the country are not a hindrance to their aspiration to start businesses. The above results confirm an earlier study by Mapfaira and Setibi (2014) that found that some of the challenges highlighted by students as hindrances to starting own businesses were difficult in accessing funds and lack of start-up technical support.

\section{Conclusions}

Based on the results above, there are a number of conclusions that can be given. First, students have a positive attitude towards entrepreneurshipand they understand and appreciate the role the programme plays in developing entrepreneurship knowledge and skills. Second, as a result of participation in the entrepreneurship education programme, many of the students show willingness to engage in entrepreneurship activities after completing schooling. Third, age and area of specialisation have no influence on the attitude of students towards entrepreneurship education while gender has an influence. Fourth, challenges that have a potential of affecting the motivation of students to participate in entrepreneurship activities after completing school include accessing seed money as well as a lack of business opportunities. Finally, it is also concluded that legislation in Botswana is very conducive to the promotion of entrepreneurship activities.

\section{Recommendations}

Based on the above conclusions, there are a number of recommendations that can be made. First, lecturers teaching entrepreneurship education need to be more specific on the sources of finance available to students and how exactly they can access these funds. Second, and as a follow-up to the above recommendation, lecturers teaching entrepreneurship need to invite, as part of teaching, members from institutions that provide loans for start-up business, to 
come and address students on the technicalities involved in the successful application for loans. Third, more needs to be done by lecturers to help students become more able to identify business opportunities. In this regard, more of case studies can help. Fourth, as part of teaching entrepreneurship education, lecturers need to make the teaching more practical by linking students with institutions that are known to provide technical start-up support so that before the students complete the course they are aware of these institutions and how to use them when they need information about how to start and run their businesses. Fifth, institutions need to come up with data bases of students who were able to start their own businesses so that they can monitor and provide technical support where needed.

\section{References}

Amdam L. A., (2011). Influence of Socio cultural factors on consumer buying behaviour in Borno state. Unpublished dissertation, university of Maiduguri.

Basu, A. \& Virick, M.(2008). Assessing entrepreneurial intentions amongst students: A comparative study. Retrieved from http://works.bepress.com/anuradha_basu/12/ [Accessed: December 15, 2015].

Bergh, P., S. Thorgren and Wincent.J. (2011). Entrepreneurs learning together: The importance of building trust for learning and exploiting business opportunities. International Entrepreneurship Management Journal 7: 17-37.

Bilic, I., Prka, A. \&Vidovic,, G. (2011). How does Education Influence Entrepreneurship Orientation? Case Study of Croatia.Management, 16 (1): $115-128$.

Botswana Review of Commerce and Industry (2007-2008).27th edition, Bandit Directories, (PTY) LTD.

Botswana Vision (2016).Retrieved from http://www.vision2016.co.bw/tempimg/media/mediac_151.pdf. [Accessed27th December 2015].

Botswana Youth Magazine, (2015). 10 institutions offering business funding support for Botswana youths.Retrieved from http://www.notswanayouth.com. [Accessed: $5^{\text {th }}$ January 2016].

Cloete, N., Bailey, T., Pillay, P., Bunting, I., \& Maassen, P (2011). Case study: Botswana and University of Botswana.Universities and economic development in Africa, 1-131.

Creswell, J. W. \& Plano Clark, V.L. (2011).Designing and conducting mixed methods

research. (2nd ed.). Thousand Oaks, CA: Sage.

Creswell, J.W, (2012). Educational Research: Planning, conducting and evaluating quantitative and qualitative research, $4^{\text {th }}$ ed. Boston, MA: Pearson Education.

Creswell, J.W, (2005). Educational Research: Planning, conducting and evaluating quantitativeand qualitative research, $2^{\text {nd }}$ ed. Thousand Oaks, California: Sage Publications.

Denanyoh, R., Adjei, K. \&Nyemekye, G.E. (2015).Factors that impact on entrepreneurship intention of tertiary students in Ghana.International Journal of Business and Social Research, 5(3): 19-29.

Ediagbonya, $\mathrm{K}$, (2013). The roles of entrepreneurship education in ensuring economic empowerment and development.Journal of Business Administration and Education, 4(1): 35-46

Emmanuel, E.A.O., Dazala, I.U. \& Daniel, J.D. (2012).Entrepreneurship education and attitude of undergraduate students to selfemployment in Mubi, Adamawa State, Nigeria.Journal of Education and Practice, 3(8): 95-102.

Ekpoh, U.I. \&Edet, A.O. (2011).Entrepreneurship Education and Career Intentions of Tertiary EducationStudents in Akwalbom and Cross River States, Nigeria.www.ccsenet.org/ies.International Education Studies,4(16): 127-139.

Eugene, A.C., Adline, A.C. \&Agwubuike, E.O. (2013). Effective management and delivery of entrepreneurship education: Implications and perceptions of non-business inclined undergraduates of NnamdiAzikiwe University, Awka. International Journal of Economy, Management and social Sciences, 2(6): 438-447.

Fayolle, A.; Klandt, H. (2006).International Entrepreneurship Education - Issues and Newness.Edward Elgar, Cheltenham, UK.Frazao, L., Santos, C., Oliveira. S. \&T. Oliveira, T. (2010). Teaching Entrepreneurship in Higher Education: The students' Perceptions. Retrieved from www.tmpk.univ-obuda.hu. [Accessed 17 January 2016].

Global Entrepreneurship Monitor (GEM) (2006).Retrieved from http://www.gemconsortium.org/.[Accessed: 27 th December 2015].

GEM, (2010), Global Entrepreneurship Monitor. Available at: http://www.gemconsortium.org/. [Accessed: $5^{\text {th }}$ January 2016].

Gerba, D.T. (2012). Impact of entrepreneurship education on entrepreneurial intentions of business and engineering students inEthiopia. African Journal of Economic and Management Studies, 3 (2): 258-277

Grozdanić, R. et al. (2008).Female Entrepreneurship in Serbia, Proceedings of the International Conference on Challenges of Economic Sciences in the 21st Century. Institute of Economic Sciences. Belgrade.

Honig, B. (2004). Entrepreneurship Education: Toward a Model of Contingency-based Business Planning. Academy of Management Learning and Education, 3(3): 258-273.

Iqbal, A., Melhem, Y.\&Kokash, H. (2012). Readiness of the university students towards entrepreneurship in Saudi private university: An exploratory study. European Scientific Journal, 8(15): 109-131.

Ismail,A. Abdullah, A.G.K., \&Othman, A.T. (2010). Acceptance of entrepreneurship culture module at theMalaysian Institutes of Higher Learning : A gender Perspective. Research Journal of International studies, 1(15): 13-21.

Kabui, E.W.\&Maalu, J.K. (2012). Perception of entrepreneurship as a career by students from selected public secondary schools in Nairobi. DBA African Management Review, 2(3): 101-120.

Kauffman Foundation, (2000).Entrepreneurship Policy: Theory and Practice.Retrieved from https://books.google.co.bw/books?isbn= 
0387242023. [Accessed 10th January 2016].

Keat, O.Y., Selvarajah, C. \&D. Meyer, (2011). Inclination towards entrepreneurship among university students: An empirical study of Malaysian university students. Internal Journal of Business and Social Sciences, 2(4): 206-220.

Kirby, D. A. (2004). Entrepreneurship education: Can business schools meet the challenge? Education + Training 46(8/9): 510-519.

Kowalczyk, D, (2015). Descriptive Research Design: Definition, Examples \& Types. Retrieved from http://study.com/academy/lesson/ descriptive-research-design-definition-examples-types.html. [Accessed: $4^{\text {th }}$ January 2016].

Lekoko, M. (2011).Students' perceptions regarding entrepreneurship education: Acase of Two Universities in Botswana. MTech dissertation, Pretoria, Tshwane University of Technology.

Lekoko, >, Rankumise, E.M.\&Ras, P. (2012). The effectiveness of entrepreneurship education: what matters most? African Journal of Business Management, 6(51): 12023-12033.

Mafela, L, (2009). Entrepreneurship education and community outreach at the University of Botswana. Eastern Arica Social Science Research Review, 25(2): 31-52.

Mani, U.A.U, (2008). Customer attitude toward interest free banking in Maiduguri.Unpublished Dissertation.

Mapfaira, H.\& Setibi, G. (2014).Enterprise and entrepreneurship education: Promoting an enterprising culture among students. Retrieved from www.fes-botswana.org.[Accessed: $8^{\text {th }}$ January 2016].

Mazura M \&Norasmah, O(2011).Consulting-based entrepreneurship education in Malaysian higher education institutions. International Conference on Social Science and Humanity 5: 163-167.

Mcstay, D, 2008. An investigation of undergraduate student self-employment intention and the impact of entrepreneurship education and previous entrepreneurship experience. PhD Thesis submitted to the School of Business, Bond University, Australia.

Mokaya, S.O., Namusonge, M.\&Sikalieh, D. (2012). The concept of entrepreneurship; in pursuit of a universally acceptable definition. International Journal of Arts and Commerce, 1(6):128-135

Mustapha, M.\&Selvaraju, M. (2015). Personal attributes, family influences, entrepreneurship education and entrepreneurship inclination among university students. Kajian Malaysia, 33(1): 155-172.

Opoku-Antwi, G.L., Appiah, K., Nyamaah-Kuffour, K.\&Yakubu, A. (2012).Entrepreneurship intentions among senior high school students in the Sunyani Municipality.International Review of Management and Marketing, 2(4): 210-219.

Pour, M.S., mooriace, M.H. \&Heydari, J. (2013). University Students' Entrepreneurial Intentions: Perceptions of Commerce Students at Tehran region. Procedia-Social and belh Sciences, 93: 1805 - 1810

Pulka, B.M., Rikwentishe, R. \&lbrhain, B. (2014). Evaluation of Students' Attitude towards entrepreneurship education in some selected universities in North East Nigeria. Global Journal of Management and Business Research, 14 (8): 1-8.

Ramalan, R.\&Ngah, S. (2012). Teaching entrepreneurship at Universiti Kuala Lumpur-British Malaysian Institute: The students' perception and mindset. International Journal of Future Computers and communication, 1(3): 242-244.

Republic of Botswana (2003)

Shaver, K., \& Scott, L. (1992). Person, process, choice: The psychology of new venture creation. Entrepreneurship Theory and Practice, 16(2): 23-45.

Klofsten, M, (2000).Training Entrepreneurship at Universities: A Swedish Case.Journal of European Industrial Training, 24(6): $337-344$.

Souitaris, V., Zerbinati, S.\& Andreas, A. (2007). Do entrepreneurship programmes raise entrepreneurial intention of science andengineering students? The effect of learning, inspiration and resources.Journal of Business Venturing, 22(4): 566-591.

Sriram, V., Mersha, T. \& L. Herron, (2007).Drivers of urban entrepreneurship: an integrative model.International Journal of Entrepreneurial Behavior \& Research, 13(4): 235 - 251

Statistics Botswana, (2011).Botswana Core Welfare Indicators (Poverty) Survey 2009/10.Central Statistics Office. Available from: http://www.cso.gov.bw [Accessed: 12 th January 2016].

Tertiary Education Council (TEC), 2005.Tertiary Education Policy in Botswana: Challenges and Choices. Consultation Paper. Gaborone: Tertiary Education Council.

Teshome, T, (2014). Attitudes of private higher education students towards entrepreneurship: A case of distance learners in WolaitaSodo and Hossana Towns. Middle-East Journal of Scientific Research, 19(2): 277-285.

Report from the Kauffman Panel on Entrepreneurship Curriculum in Higher Education, (2007). Entrepreneurship in American Higher Education; (retrieved January 4 2016).Available from http://ssrn.com/abstract=1291290.

Republic Of Botswana.(2003). National Development Plan 9 2003/2008.Ministry of Finance and Development Planning.Gaborone. Republic of Botswana., National Development Plan 9, 2003/2008. Ministry of Finance and Development Planning, March 2003.

Zain, Z.M., Akram, A.M.\& Ghani, E.K. (2010). Entrepreneurship intentions among Malaysian Business students.Canadian Social Science, 6(3): 34-44. 